\title{
高密度実装基板におけるフリップチップリワーク法
}

\author{
森 史成*, 鳥山 和重*, 勝 直樹*, 荘司 郁夫**
}

\section{Development of Flip Chip Rework Method for High Dense Printed Circuit Board}

\author{
Fuminari MORI* , Kazushige TORIYAMA* , Naoki KATSU* and Ikuo SHOHJI**
}

\footnotetext{
*日本アイ・ビー・エム株式会社野洲事業所電子回路部品技術（テ520-2392 滋賀県野洲郡野洲町市三宅800）

**群馬大学工学部 (†376-8515 群馬県桐生市天神町1-5-1)

*Card Engineering, Yasu, IBM Japan, Ltd. (800 Ichimiyake, Yasu-cho, Yasu-gun, Shiga 520-2392)

**Faculty of Technology, Gunma University (1-5-1 Tenjin-cho, Kiryu-shi, Gunma 376-8515)
}

\section{Abstract}

Flip chip attach technology has many advantages and is considered one of the most important technology in the micro joining field. However, the flip chip rework is difficult when the flip chip bonding is formed on the high density card. We developed new flip chip rework method using the solder capped chip technology. In this technology, Sn-37Pb solder, which is neccessary to form the flip chip joint again, is applied on $\mathrm{Pb}-3 \mathrm{Sn}$ bumps of bare chip by the paste printing method. That solder capped chip was used as the replacement chip on the rework process. This report describes the development of flip chip rework method by solder capped chip.

Key Words: Flip Chip, Rework, Paste Printing, Reflow Soldering, Sn-37Pb

\section{1. 緒 言}

電子機器の軽薄短小化, 高機能化の要求は電子部品のみ ならず実装技術にも及び，ベアチップ実装が注目を集めて いる。中でも数々の利点を有するフリップチップ実装が注 目を集め実用化されている”。一般に, 樹脂系プリント配 線板上へはんだ接合を用いてフリップチップ接合部を形成 するためには, チップ側および基板側の両方にバンプを形 成する必要がある。チップ側のバンプ材としてはPb-3Sn (wt\%, 以下すべてwt\%表示) やAuが用いられ, 基板側 のバンプ材としてはSn-37Pbなどのはんだ材が使用される 1)。フリップチップ実装においてはこれらのバンプ形成技 術が接合部形成のための重要プロセスとなる。基板側のバ ンプ作製方法としては, ソルダインジェクション法”, ス ーパーソルダ法 ${ }^{33}$, スーパージャフィット法はなどがあるが, いずれの工法もSMT(Surface Mount Technology)部品と の混載実装の場合には, 別工程でのバンプ形成が要求され, フリップチップ搭載によりコストアップが避けられない状 況となっていた。そこでわれわれは，はんだペースト印刷 によりSMTパッドとフリップチップパッドへ同時にはん だ材を供給し, 同時部品実装を行うChip on Paste法引を開 発し，1インチ型HDD(Hard Disk Drive)に応用してきた。 Fig.1 にChip on Paste法により生産されている1インチ型 HDDの実装基板を示す。Fig. 1 の基板には，3 個のフリッ プチップと 1 個のCSPが他のSMT部品と混載されている。
Chip on Paste法により, フリップチップも他のSMT部品 と同様の部品として取り扱うことを可能にし, 同時搭載, 一括リフローすることに成功している。

Chip on Paste法の導入により, 低コストでの基板側の はんだバンプ形成およびフリップチップ実装が可能になっ たが，Fig. 1 のような高密度実装基板上でMCM(Multi Chip Module)の形態をとる場合には, フリップチップの リワークが困難となる問題が発生する。不良チップの取り 外し法としては，はんだ接合部を加熱してはんだを再溶融 させ, チップを吸着ノズル等で除去するという方法が一般 に行われており，ノズル形状の工夫により高密度実装基板 に対しても対応は可能である。しかし，新ななチップを搭 載する際には，基板側パッド上に再接合に必要なはんだバ ンプを再形成する必要があるが, 前述のいずれの方法でも, 周辺部の搭載部品を避けての再バンプ形成は困難であっ た。そこで, 本研究では再接合に必要なはんだ材をあらか じめチップ側のバンプ上に供給する方法に注目した。チッ

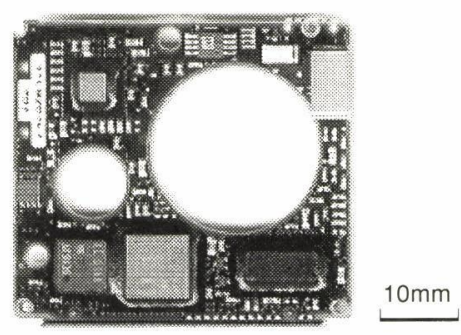

Fig.1 Main board of 1 inch type HDD 
プ側バンプへはんだ材を供給する技術として報告されてい るものには, SnをチップのPb-3Snはんだバンプに蒸着す る技術占やIn-Pb，Sn-Pbはんだペーストを印刷し，溶融さ せることにより Auスタッドバンプ上に供給するCMT法 ${ }^{7}$ と呼ばれる技術がある。前者の技術では気相蒸着法を用い るためコスト高となる欠点があり，後者の技術は形状的に 適度のはんだ量が供給されやすいAuスタッドバンプに対 する技術であり，球状のPb-3Snバンプへの適応はなされ ていない。そこで，七ラミック板へのはんだペースト印刷 を利用してチップ側のPb-3Snはんだバンプ上に接合部形 成に必要な量のSn-37Pbはんだを供給するSolder Capped Chip法を開発し，高密度基板上のフリップチップ接合部 のリワークを低コストで実現することに成功した。本報で は, Solder Capped Chip法を利用したフリップチップリワ ーク工法およびその工法を用いてリワークされた接合部の 評価結果について報告する。

\section{Solder Capped Chipによるフリップチップリワー ク工法}

\section{1 Solder Capped Chip作成法}

Fig. 2 にSolder Capped Chipの作製手順を示す。まず, $\mathrm{Sn}-37 \mathrm{~Pb}$ ペーストを用いて，七ラミック板上にチップのバ ンプパターンを印刷する。その上にPb-3Snバンプを有す るフリップチップを搭載し，リフロー炬によりはんだを溶 解し，チップ側のPb-3SnバンプにSn-37Pbはんだを需れさ せる。Sn-37Pbはんだはセラミック基板には濡れないため, 基板側のPb-3Snバンプ上にコーティングされ，リフロー 後は容易にセラミック基板からチップを取り外すことが可 能となる。本研究では水洗浄用ペーストを使用したためリ フロー後には, Solder Capped Chipを水洗浄することによ りフラックス残渣を除去した。

\section{2 フリップチップリワーク法}

Solder Capped Chipを用いたフリップチップリワーク法 をFig. 3 に示す。不良フリップチップの取り外しは，該当

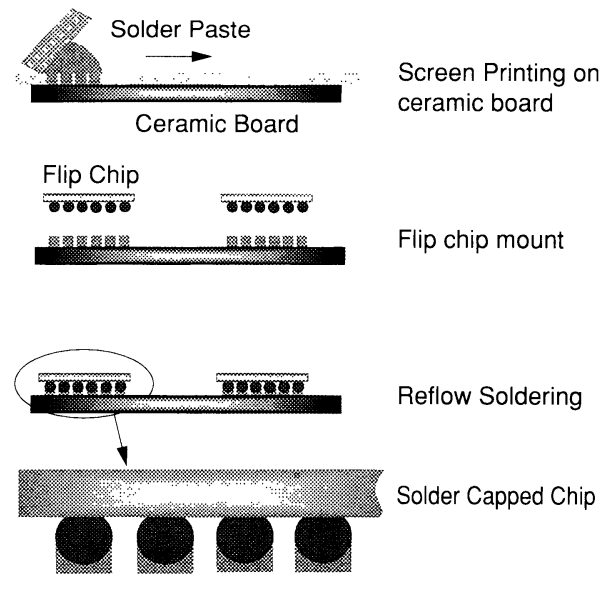

Fig.2 Schematic drawing of solder capped chip formation process
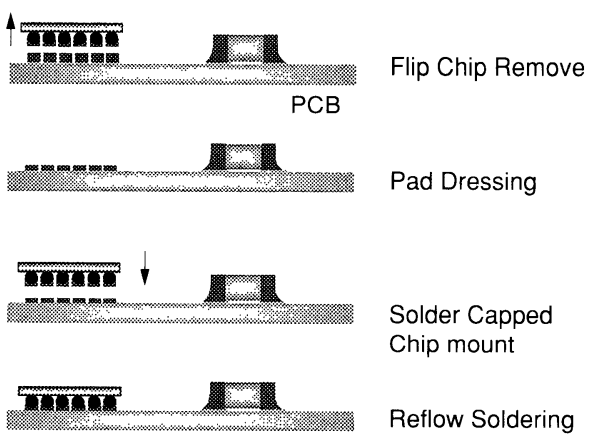

Fig.3 Schematic drawing of flip chip rework with solder capped chip

チップのはんだ接合部を加熱して再溶融させ，専用ピッカ 一により基板側からチップを取り外すことにより行った。 不良チップを除去した後の基板側への残留はんだはその高 さ（量）にばらつきがあり，またチップバンプ側 $\mathrm{Pb}-3 \mathrm{Sn}$ 成分の残留等もあるため，バンプドレッシングを行う必要 がある。バンプドレッシング工程では，こて先にSn-37Pb はんだをコーティングしたはんだごてを用いて基板側バン プを再溶融させ，基板側のフリップチップパッドに残留し たはんだの高さをそろえている。また同時に，Pb-richな 残留はんだ成分を除去することにより残留はんだ成分の均 質化も図っている。基板側はんだバンプのバンプドレッシ ング後に, Fig. 2 のように作成したSolder Capped Chipを 基板上へフラックス供給と共に搭載し，リフロー炉により 再接合を行う。リフロー後にフラックス洗浄を行うことに よりリワーク工程は完了する。

\section{3. 評価結果}

本研究では, 平均はんだ粒径 $27.2 \mu \mathrm{m}$, フラックス含有 量11wt\%のSn-37Pbはんだペーストを用いて，セラミック 板上にペースト印刷を行った。セラミック板は材質が $\mathrm{Al}_{2} \mathrm{O}_{3}$, 純度 $99.5 \%$ $\%$ のを使用した。またべアチップは チップサイズ $8.2 \times 3.3 \mathrm{~mm}$, 電極間ピッチ $320 \mu \mathrm{m}$ で $\mathrm{Pb}-3 \mathrm{Sn}$ バンプが77I/O配されたものを供した。印刷用メタルマス クは, 厚さ $0.06 \mathrm{~mm}$ ものに，ベアチップのPb-3Snバンプ 配置と同様のパターンで円形に $180 \mu \mathrm{m}$ 直径で開口したもの を使用した。

3. 1 セラミック板上への印刷性

Table 1 に，セラミック板上へはんだペースト印刷法に よって供給されたはんだバンプ体積と標準偏差を示す。バ ンプ体積は，七ラミック板上に供給されたはんだペースト を一度リフローすることにより球状にし，その径を測定す ることにより求めた。さらに比較対照として, 本研究で使

Table 1. Mean bump volume and STD (STandard Diviation)

\begin{tabular}{l|c|c}
\hline & $\begin{array}{l}\text { Volume } \\
\left(\times 10^{-4} \mathrm{~mm}^{3}\right)\end{array}$ & $\mathrm{STD}\left(\times 10^{-4} \mathrm{~mm}^{3}\right)$ \\
\hline Ceramic & 4.67 & 0.44 \\
\hline Build up PCB & 6.10 & 0.67 \\
\hline
\end{tabular}


用したベアチップを実装することが可能な電極パターンを もつビルドアップ基板上に同じはんだペーストを使用して 印刷を行ったときの結果もあわせてTable 1 に示すすったの 際に使用したメタルマスクの厚さは $0.06 \mathrm{~mm}$, 開口径は $175 \mu \mathrm{m}$ であった。

Table 1の結果より，七ラミック板上へのはんだペース ト印刷では，ビルドアップ基板の場合と比較して平面度が 良好に保たれているため, 供給量のばらつきの少ないバン プ形成が可能であることがわかる。また，ビルドアップ基 板への印刷時にはより開口径の小さなメタルマスクを使用 しているにもかかわらず，セラミック板上への印刷よりも 供給バンプ体積が大きい。その理由としては, ビルドアッ プ基板の表層レジスト表面よりも銅電極の表面がより低い 位置にあるため，ペースト供給部は凹型形状を呈する。そ のため, 平面上への印刷となるセラミック板への印刷と比 較して，ビルドアップ配線板上への印刷では，はんだぺー ストがより多く供給されたためと考える。

\section{2 はんだ接合部観察結果}

2.1項で示した手順で作製したSolder Capped Chipのバ ンプ断面観察結果をFig. 4 に示す。なおリリフー条件とし ては，ピーク温度 $210^{\circ} \mathrm{C}$ ，はんだの溶融時間 $125 \mathrm{~s} の$ 条件で 行った。Fig. 4 より，チップ側のPb-3Snバンプの表面に Sn-37Pbはんだが良好にコーティングされていることがわ かる。また，七ラミック板上でリフローソルダリングを行 うため，バンプ底面が平面を形成していることがわかる。 この平面形状は球面状のバンプ形状と比較して, Solder Capped Chipをリワーク基板に搭載する際に，搭載ずれを 起こしにくくなる効果も期待できる。

作製したSolder Capped Chipを使用して，2.2項に示し た手順でリワークを行ってみた。リワーク時のリフロー条

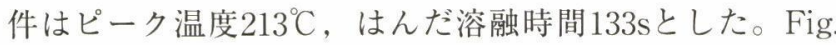
5 に初期接合とリワーク接合の接合部断面観察結果を示 す。本方式によるリワーク接合部は初期接合部と比べても 遜色のない良好な接合部形状を形成していることがわか る。

\section{3. $3 \mathrm{~Pb}-3 \mathrm{Sn}$ バンプヘの濡れ性}

Solder Capped Chip作製時に, Pb-3Snバンプ全面へSn37Pbはんだが濡れ拡がらず，Sn-37Pbはんだの濡れ不良が 見受けられるものが存在した（Fig. 6 (a)参照）。このよう な濡れ不良を有するSolder Capped Chipのバンプに液状つ

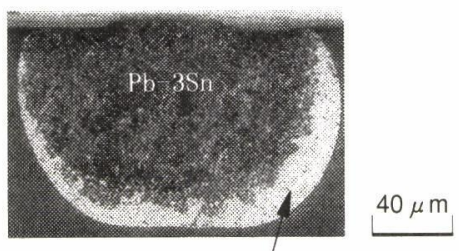

$\mathrm{Sn}-37 \mathrm{~Pb}$

Fig.4 Cross sectional view of solder capped chip

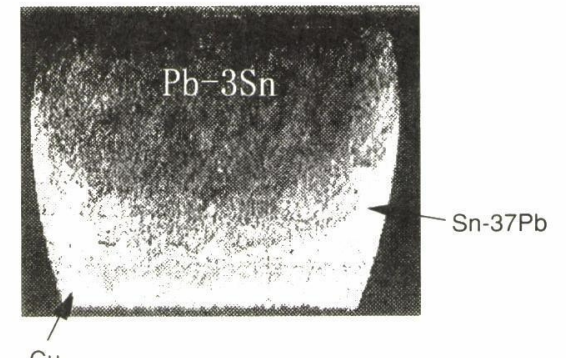

(a) reworked joint

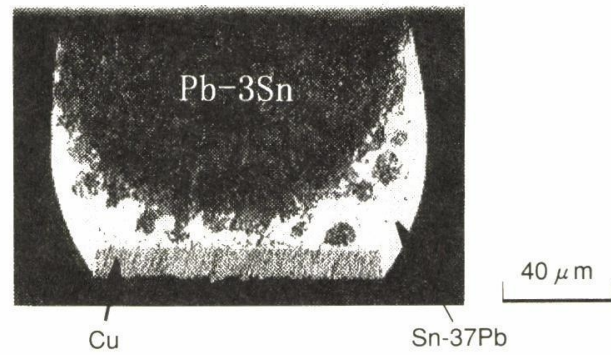

(b) initial joint

Fig.5 Cross sectional views of flip chip joints

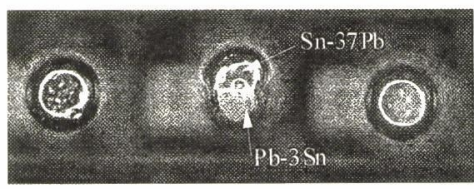

(a) poor wet bump

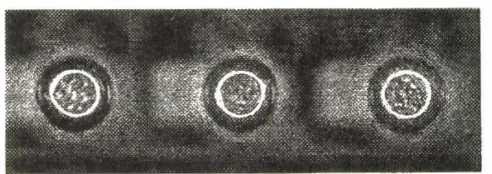

(b) reworked bump

Fig.6 Photographs of solder capped chip

ラックスを塗布し，セラミック板上に搭載後，再リフロ 一を行ったところ, Fig. 6 (b)に示すように濡れ不良が改善 されることがわかった。また濡れ不良を修正せずにFig. 6 (a)のような形状のままでフリップチップリワークを行っ たところ，Fig. 5 で示したような通常の接合部が得られる ことが確認できた。しかし，Fig. 6 (a)のような濡れ不良バ ンプを持つチップを使用してリワークを行う際には，通常 のSolder Capped Chipよりもより高精度の搭載精度が要求 されるため, 濡れ不良バンプは再リフローを行ってバンプ リワークを行うべきであると考える。またSolder Capped Chipを作製するときのリフロー条件のピーク温度設定を より高温にし，はんだ溶融時間をより長くしてみても濡れ 不良の発生頻度に差がなかったこと, 保管条件を厳密に管 理したチップでは濡れ不良がほとんど起きないことから， 濡れ不良発生はPb-3Snバンプの表面酸化状態に影響され るものと考える。

\section{4 基板側残留はんだの影響}

Solder Capped Chipを用いてフリップチップリワークを 行ったところ，Fig. 7 に示すような接合不良が見られるこ とがあった。Solder Capped Chip作製時にはFig. 4 に示し たようにバンプ先端部は平面形状になっているが，Fig.7 


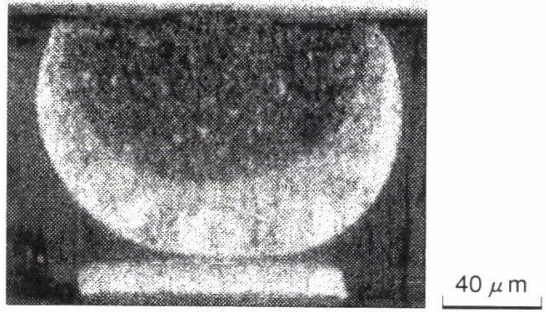

Fig.7 Cross sectional view of non-connected joint

のSolder Capped Chipのバンプ先端部は平面ではなく球面 になっている。このことよりSn-37Pbはんだは溶融したも のの基板側電極上に濡れ拡がらず，接合しなかったものと

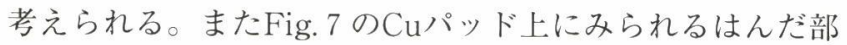
はほとんど厚みがなく平面状であることから，Cuパッド 表面にはSn-37Pbはんだがほとんどなく, Cu-Sn系の金属 間化合物が表面に露出していると考えられる。不良フリッ プチップのリムーブ後には，はんだごてを用いて基板上の 残留はんだに対してバンプドレッシングを施して残留はん だの高さをそろえるが (2.2項参照)，この際にこて先に付 着しているはんだにCuパッド上の残留はんだのほとんど が吸い上げられ，はんだ層の下面のCu-Sn系の金属間化合 物層が露出したものと考える。したがって, Fig. 7 のよう な接合不良を防止するためには，バンプドレッシング工程 にてリワークされる基板側 $\mathrm{Cu}$ 電極上に金属間化合物が露 出しないよう工程管理する必要があることがわかった。

\section{4. 接合部信頼性}

Solder Capped Chipを用いてリワークしたフリップチッ プ接合部の信頼性評価をするために，熱サイクル試験と高 温高湿バイアス試験を行った。各試験は接合部に樹脂封止 を行った上で行った。Table 2 に試験条件抢よび試験結果 を示す。両試験とも良好な結果が得られており，本方式に よりリワークされたフリップチップ接合部は，実用上問題 ないレベルの信頼性が得られていることがわかる。

\section{5. 結 論}

本研究では, 高密度実装基板上に搭載されたフリップチ ップをリワークするための技術として，チップ側の高融点 はんだバンプ上に再接合に必要な量のSn-37Pb共晶はんだ を供給し、リワーク用チップとして使用する工法を開発し た。本研究で得られた成果を以下にまとめる。

(1) ベアチップのPb-3Snバンプ上へ接合用のSn-37Pbは んだ材を供給するSolder Capped Chip法を開発した。

(2) セラミック板上へのはんだペースト印刷は,ビル
Table 2. Reliability test conditions and results

\begin{tabular}{l|l|c|c} 
& conditions & $\mathrm{N}$ & results \\
\hline \multirow{3}{*}{ TC } & $-25-115^{\circ} \mathrm{C}$, & & \\
& 2 cycle/hour. & 12 & pass \\
& 800 cycles & & \\
\hline \multirow{3}{*}{ THB } & $85^{\circ} \mathrm{C}, 85^{2} \% \mathrm{RH}$. & & \\
& $3.6 \mathrm{~V}$, & 12 & pass \\
& 500 hours & & \\
\hline
\end{tabular}

ドアップ基板への印刷よりも安定して行うことができ る。

(3) $\mathrm{Pb}-3 \mathrm{Sn}$ バンプ上への Sn-37Pbはんだの濡れ性は, $\mathrm{Pb}-3 \mathrm{Sn}$ バンプ表面の表面酸化により影響を受ける。

(4) バンプドレッシング後の基板側電極上の残留はん だ量が少なく, Cu-Sn系金属間化合物層が露出してい る場合には，Solder Capped Chipの搭載時に濡れ不良 を起こす。

(5) 本工法によりリワークされたフリップチップ接合 部は，実用上十分なレベルの信頼性を有することが確 認された。

(2000.1.11-受理)

\section{文献}

1) 折井靖光, 荘司郁夫, 酒井俊廣: “ノートパソコンに扔ける MCM-Lの奏装技術”，電子材料，pp.67-71，9 月号， 1995

2) Y.Kodama, T.Matsumoto and Y.Tsukada: "Carrier Bump Build by Molten Solder Injection”, Proceedings of 9th IMC, pp.286-290, 1996

3）天野俊昭，日笠和人：“スーパーソルダーを用いた半田バン プ形成について”，第25回マイクロ接合研究委員会ソルダリ ング分科会資料, pp.27-36, 1998

4）堺 丈和，荘司孝志：“スーパージャフィット（SJ）法によ るはんだバンプ形成技術”，第25回マイクロ接合研究委員会 ソルダリング分科会資料，pp.37-44，1998

5) 鳥山和重, 藤内伸一, 折井靖光：“ペースト印刷法によるフ リップチップ接合技術の開発”, Proc.of Microjoining and Assembly Technology in Electronics'99, pp.177-182, 1999

6) 森 日出雄, 山田 毅, 毛吕健一: “Tin-Capped Bumpを 用いたフレックスケーブル上へのフリップチップ実装技術 開発”, Proc. of Microjoining and Assembly Technology in Electronics '99, pp.173-176, 1999

7) 佐原隆一, 國友美信, 斉藤 彰, 阪下靖之, 津田俊雄, 北 山喜文：“Auスタッドバンプを用いたフリップチップ実装 工法の開発”, 第32回マイクロ接合研究委員会資料, pp.6578,1992 